\title{
AN INTEGRATIVE DESCRIPTION OF A NEW RICHTERSIUS SPECIES FROM GREECE (TARDIGRADA: EUTARDIGRADA: RICHTERSIUSIDAE)
}

\author{
Justyna Pogwizd $^{1}$ and Daniel Stec ${ }^{1,2 *}$ \\ ${ }^{1}$ Department of Invertebrate Evolution, Institute of Zoology and Biomedical Research \\ Faculty of Biology, Jagiellonian University, Gronostajowa 9-, 30-387 Kraków, Poland \\ E-mail: justynapogwizd98@onet.pl,https://orcid.org/0000-0003-3986-6007 \\ ${ }^{2}$ Institute of Systematics and Evolution of Animals, Polish Academy of Sciences \\ Stawkowska 17, 31-016 Kraków, Poland; *corresponding author: daniel.stec@isez.pan.krakow.pl, \\ https://orcid.org/0000-0001-6876-0717
}

In this paper, we describe a new tardigrade species, Richtersius tertius sp. n., from Greece. The description is based on morphological and morphometric analysis using light and scanning electron microscopy as well as genetic analysis based on four molecular markers (DNA sequences of three nuclear, i.e., 18S rRNA, 28S rRNA, ITS-2 and one mitochondrial COI fragment). Morphological and morphometric differences, together with genetic comparisons, provide independent verifications of Richtersius tertius sp. n. as a species new to science. Phenotypically, the new taxon differs from Richtersius coronifer (Richters, 1903) and Richtersius ziemowiti Kayastha, Berdi, Miaduchowska, Gawlak, Łukasiewicz, Gołdyn, Jędrzejewski et Kaczmarek, 2020 mainly by the morphology and size of cuticular pores, present only in hatchlings (first instars), as well as some morphometric characters. The results presented herein contribute further to the recognition of the morphological variability and biodiversity within Richtersius, with Richtersius tertius sp. n. being the third species formally described within the genus.

Key words: biodiversity, integrative taxonomy, Richtersius tertius sp. n., systematics.

\section{INTRODUCTION}

Water bears (Tardigrada), also known as moss piglets, are a globally distributed phylum of microscopic metazoans related to arthropods and onychophorans that inhabit terrestrial, marine and freshwater environments (CAMPBELl et al. 2011, Nelson et al. 2015). To date, over 1300 species of tardigrades have been found and described (Guidetti \& Bertolani 2005, Degma \& GuiDetTi 2007, Degma et al. 2009-2021). Although tardigrade taxonomy is challenging because of their microscopic size and a small number of taxonomically informative characters (KoszTyŁA et al. 2016, Morek et al. 2016), over a dozen species new to science are described every year, further expanding our knowledge on their biodiversity (Michalczyк \& KaczMareк 2013).

Richtersius coronifer (Richters, 1903), originally described as Macrobiotus coronifer Richters, 1903, is characterised by large body size (up to a $1 \mathrm{~mm}$ in length), yellowish colour, mouth opening surrounded with a circular velum, 
beak-shaped teeth of the third band in the oral cavity, thick-walled buccal tube with a narrow light, pharynx containing macroplacoids but not microplacoids, and claws on all legs equipped with strongly and regularly dentate lunulea. Since there was no type material of M. coronifer, MaUcCi and RAMAzzотті (1981) redescribed the species and simultaneously transferred it to the newly erected genus Adorybiotus Maucci et Ramazzotti, 1981. However, the detailed morphological comparison with Adorybiotus granulatus (Richters, 1903) and Adorybiotus coronifer (Richters, 1903) by Pilato and Binda (1987) allowed the taxon to be redefined and established as the type species for a new monotypic genus Richtersia Pilato et Binda, 1987. After two years, due to the homonymy of the proposed name with a generic name within the Nematoda, the genus name was changed once again, from Richtersia to Richtersius by Pilato and Binda (1989). For many years Richtersius remained monotypic, containing only $R$. coronifer, a species considered to have a cosmopolitan distribution (McInNes 1994, KaCZMAReK et al. 2015, KaCZMAREK et al. 2016, MCINNES et al. 2017). A century after it was described, the first analyses of molecular data obtained for $R$. coronifer indicated that there were more than one species hidden within the genus Richtersius (ReBecchi et al. 2003, FAurby et al. 2008). These results were later confirmed by GuidetTr et al. (2016), who, based on morphological and genetic analyses, established the family Richtersiidae Guidetti, Rebecchi, Bertolani, Jönsson, Kristensen et Cesari, 2016. The new family included three genera: Richtersius, Adorybiotus and the then newly erected Diaforobiotus Guidetti, Rebecchi, Bertolani, Jönsson, Kristensen et Cesari, 2016, that comprises species of the former informal Macrobiotus islandicus group. The phylogenetic relationships within the proposed family were unclear since Adorybiotus was more closely related to the family Murrayidae Guidetti, Gandolfi, Rossi et Bertolani, 2005 than to the other richtersiid genera. Nevertheless, Adorybiotus was tentatively included within Richtersiidae because of morphological similarities with Richtersius and Diaforobiotus (GUIDETti et al. 2016). The research mentioned above, dealing with the genus Richtersius, clearly indicates that global records of " $R$. coronifer" are likely to represent a species complex rather than a single ubiquitous species (RевесCHi et al. 2003, Faurby et al. 2008, Guidetti et al. 2016, Stec et al. 2020a). To allow a formal description of species within the complex, STEC et al. (2020a) redescribed $R$. coronifer using a population collected from one of the two localities in Spitsbergen mentioned in the original description. To secure and stabilise the taxonomy of the genus Richtersius an integrative approach to the redescription was adopted and linked with setting aside the neotype designated by MaucCi and Ramazzotti (1981) and with the designation of the new neotype (Stec et al. 2020a, Stec \& MichalczyK 2020). The effects of the redescription are already noticeable, as recently a second species in the genus, Richtersius ziemowiti Kayastha, Berdi, Mioduchowska, Gawlak, Łukasiewicz, Gołdyn, 
Jędrzejewski et Kaczmarek, 2020, was described from Nepal (previously reported as R. coronifer by Kayastha et al. 2020b).

In addition to the redescription of $R$. coronifer published at the beginning of 2020, the year was an intense period regarding changes made within the systematics of the family Richtersiidae. Specifically, the new genus Crenubiotus Lisi, Londoño et Quiroga, 2020 was erected using classical taxonomic methods and detailed morphological examination of the animals and eggs of Macrobiotus crenulatus (Richters, 1904) as well as those of a very similar new species from Colombia, and then placing the new genus within the family Richtersiidae. Subsequently, Sтес et al. (2020b) integratively redescribed Crenubiotus crenulatus, pinpointing its phylogenetic position within Macrobiotoidea. The analysis, in addition to the new genetic data for two analysed Crenubiotus species, also included novel genetic data for Adorybiotus cf. granulatus, demonstrating the presence of a distinct evolutionary lineage composed of Adorybiotus and Crenubiotus. In order to acknowledge the phylogenetic and morphological distinctiveness of this lineage, (STEC et al. 2020b) erected a new family, Adorybiotidae Stec, Vecchi et Michalczyk, 2020. Soon after, Guidetri et al. (2021) described an additional new Crenubiotus species from Germany, presenting its phylogenetic position that was congruent with the results provided by STEC et al. (2020b). Moreover, Guidetti et al. (2021) changed the name of the family Richtersiidae into Richtersiusidae Guidetti, Schill, Giovannini, Massa, Goldoni, Ebel, Förschler, Rebecchi et Cesati, 2021, because the former was a junior homonym of a nematode family. As a result of the systematic and nomenclatural changes, the family Richtersiusidae now includes two genera, Richtersius and Diaforobiotus, with the first of these comprising only two nominal species, $R$. coronifer and $R$. ziemowiti.

In this study, we re-examined the Richtersius population from Greece previously studied by STEC et al. (2020a) and described and designated it as a new species. Our research utilised an integrative taxonomy approach, involving detailed morphological and morphometric examination under phase contrast light microscopy (PCM) as well as scanning electron microscopy (SEM), linked with genetic data already obtained for this population in the study mentioned above.

\section{MATERIAL AND METHODS}

Samples and specimens - A mixed moss and lichen sample was collected on 4 July 2015 from a tree in a forest on the Greek island of Crete (Omalos, Chania). The sample was examined for tardigrades using the protocol by DАSтүсн (1980), with modifications described in detail in STEC et al. (2015) for the purpose of the earlier study by STEC et al. (2020a). Animals and eggs were extracted from the sample and split into several groups for specific analyses, i.e. morphological analysis in PCM and SEM, as well as DNA sequencing (for details, see "Material examined" provided below in the result section of the species description). 
Microscopy and imaging - Specimens for light microscopy were mounted on microscope slides in a small drop of Hoyer's medium and secured with a coverslip, following MoreK et al. (2016) protocol. Slides were examined under an Olympus BX53 light microscope with phase contrast associated with an Olympus DP74 digital camera. To obtain clean and extended specimens for SEM analysis, tardigrades were processed according to STEс et al. (2015) protocol. Specimens were examined under high vacuum in a Versa 3D DualBeam Scanning Electron Microscope at the ATOMIN facility of the Jagiellonian University, Kraków, Poland. All figures were assembled in Corel Photo-Paint X8. For structures that could not be focused in a single photograph, a stack of 2-10 images were taken with an equidistance of ca. $0.2 \mu \mathrm{m}$ and assembled manually into a single deep-focus image.

Morphometrics and morphological nomenclature - All measurements are given in micrometres $(\mu \mathrm{m})$. The sample size was adjusted following recommendations by STEC et al. (2016). Structures were measured only if their orientation was suitable. Body length was measured from the anterior to the posterior extremity of the body, excluding the hind legs. The terminology used to describe the oral cavity armature and eggshell morphology follow Kaczmarek and Michalczyк (2017), Guidetti et al. (2016) and Stec et al. (2020a, b). Macroplacoid length sequence is given according to KAczMAREK et al. (2014). Buccal tube length and the level of the stylet support insertion point were measured according to PILato (1981). The $p t$ index is the ratio of the length of a given structure to the length of the buccal tube expressed as a percentage (Pilato 1981). Buccal tube width was measured as the external and internal diameter at the level of the stylet support insertion point. Heights of claw branches were measured according to KACZMAREK and MichalczYK (2017), i.e. from the base of the claw (i.e. excluding the lunulae) to the top of the branch, including accessory points. The claw common tract index (cct) is the proportion of the height of the common tract of the claw (measured from the claw base to the separation point between the first and the second branch) to the total claw height expressed as a percentage (GuideTti et al. 2016). The description of cuticular bars on legs follows Kiosya et al. (2021). The distance between egg processes was measured as the shortest span between the base edges of the two closest processes. Following Stec et al. (2020a), we measured six additional traits: cuticular pore density (PD, the number of pores per $2500 \mu^{2}$ counted within a rectangle on the dorsal cuticle between legs III and IV), pore size (PS, measured as largest diameter; ten pores per measured specimen), the number of teeth on the external and internal lunulae III (ExtT and Int T, respectively) and the number of teeth on the anterior and posterior lunulae IV (AntT and PosT, respectively). Morphometric data were handled using the "Parachela" ver. 1.8 template available from the Tardigrada Register (МiснацсZYк \& KaсzмAREк 2013) and are provided as Supplementary Material (SM.01 and SM.02). Tardigrade taxonomy follows Bertolani et al. (2014), Stec et al. (2020b) and Guidetti et al. (2021).

Comparative molecular analysis - For molecular comparisons, all published sequences of the 18S rRNA, 28S rRNA, ITS-2 and COI markers of suitable length, and homological fragments for the genus Richtersius were downloaded from GenBank (Table 1). The sequences were aligned using the default settings (in the case of COI and ITS-2) and the QINS-I method (in the case of $18 \mathrm{~S}$ rRNA, 28S rRNA) of MAFFT version 7 (КАтон et al. 2002, КАТОН \& Тон 2008) and manually checked against non-conservative alignments in BioEdit. The aligned sequences were trimmed to: 764 (18S rRNA), 762 (28S rRNA), 442 (ITS-2), 641 (COI), bp. All COI sequences were translated into protein sequences in MEGA7 version 7.0 (Kumar et al. 2016) to check against pseudogenes. Uncorrected pairwise distances were calculated using MEGA and are provided as Supplementary Material (SM.03). 


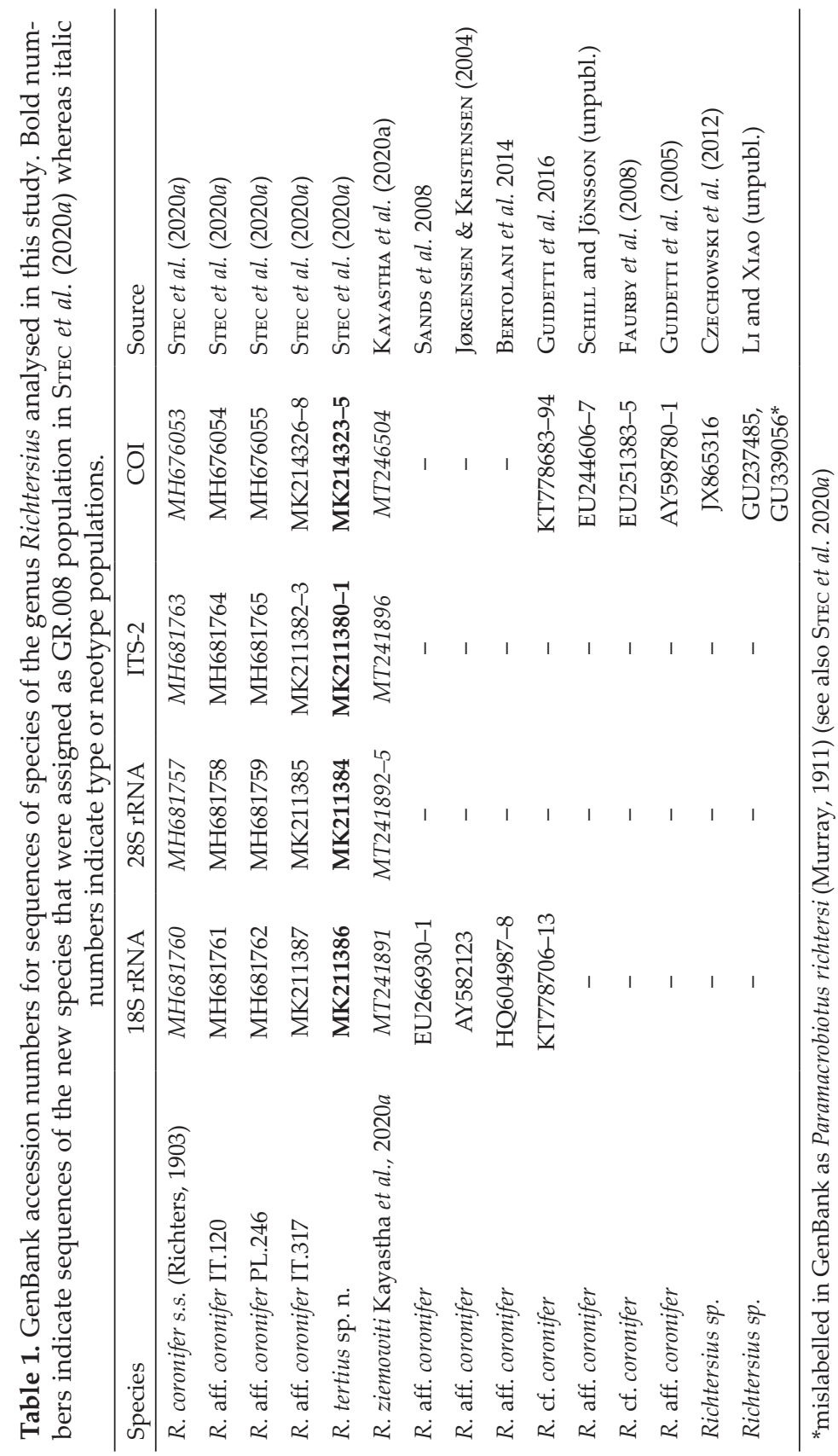




\section{RESULTS}

Phylum: Tardigrada Doyère, 1840

Class: Eutardigrada Richters, 1926

Order: Parachela Schuster, Nelson, Grigarick et Christenberry, 1980

Superfamily: Macrobiotoidea Thulin, 1928

Family: Richtersiusidae Guidetti, Schill, Giovannini, Massa, Goldoni, Ebel, Förschler, Rebecchi et Cesari, 2021

Genus: Richtersius Pilato et Binda, 1989

\section{Richtersius tertius sp. n.}

(Figs 1-7)

Richtersius sp. 7 (GR.008; MK214323-5) in STEC et al. 2020a

Richtersius sp. (OTU6; MK214323-5) in Kayastha et al. 2020a

Etymology: The name "tertius" refers to the fact that the new species is the third formally described in the genus Richtersius.

Material examined: 171 animals and 73 eggs: specimens mounted on microscope slides in Hoyer's medium (134 adult animals +12 hatchlings +59 eggs), fixed on SEM stub $(12+9+14)$, and used for DNA extraction and sequencing $(4+0+0$; in STEC et al. 2020a).

Description of the new species - Adults (measurements and statistics in Table 2).

Table 2. Measurements [in $\mu \mathrm{m}$ ] and $p t$ values of selected morphological structures of adults of Richtersius tertius sp. n. excluding hatchlings. (Specimens mounted in Hoyer's medium; $\mathrm{N}=$ number of specimen/structures measured, Range refers to the smallest and the largest structure among all measured specimens; $\mathrm{SD}=$ standard deviation).

\begin{tabular}{|c|c|c|c|c|c|c|c|c|c|}
\hline \multirow{2}{*}{ Character } & \multirow[t]{2}{*}{$\mathrm{N}$} & \multicolumn{2}{|c|}{ Range } & \multicolumn{2}{|c|}{ Mean } & \multicolumn{2}{|c|}{ SD } & \multicolumn{2}{|c|}{ Holotype } \\
\hline & & $\mu \mathrm{m}$ & $p t$ & $\mu \mathrm{m}$ & $p t$ & $\mu \mathrm{m}$ & $p t$ & $\mu \mathrm{m}$ & $p t$ \\
\hline Body length & 30 & $608-904$ & - & 753 & & 75 & & 866 & \\
\hline \multicolumn{10}{|c|}{ Buccal tube } \\
\hline Buccal tube length & 30 & $65.1-90.8$ & - & 77.9 & - & 5.7 & - & 81.2 & - \\
\hline Stylet support insertion point & 30 & $43.1-59.4$ & $65.3-68.9$ & 52.5 & 67.3 & 4.1 & 1.1 & 53.6 & 66.0 \\
\hline Buccal tube external width & 30 & $4.0-7.3$ & $5.6-8.8$ & 5.9 & 7.5 & 0.8 & 0.8 & 6.1 & 7.5 \\
\hline Buccal tube internal width & 30 & $1.6-2.3$ & $2.0-3.1$ & 1.9 & 2.5 & 0.2 & 0.3 & 1.9 & 2.3 \\
\hline Ventral lamina length & 30 & $24.6-40.1$ & $37.8-48.9$ & 34.3 & 43.9 & 3.6 & 2.8 & 32.5 & 40.0 \\
\hline \multicolumn{10}{|c|}{ Placoid lengths } \\
\hline Macroplacoid 1 & 30 & $10.3-15.2$ & $13.7-19.5$ & 12.7 & 16.4 & 1.1 & 1.7 & 14.9 & 18.3 \\
\hline Macroplacoid 2 & 30 & $5.3-9.9$ & $6.9-13.1$ & 8.5 & 10.9 & 0.8 & 1.1 & 8.6 & 10.6 \\
\hline Macroplacoid row & 30 & $19.1-25.4$ & $25.3-32.6$ & 22.2 & 28.6 & 1.4 & 2.0 & 25.4 & 31.3 \\
\hline \multicolumn{10}{|c|}{ Claw I heights } \\
\hline External base & 24 & $9.1-15.8$ & $12.8-19.9$ & 12.1 & 15.4 & 1.6 & 1.7 & 12.2 & 15.0 \\
\hline External primary branch & 24 & $16.1-25.0$ & $23.8-31.6$ & 21.5 & 27.4 & 1.9 & 2.1 & 23.1 & 28.4 \\
\hline
\end{tabular}


Table 2 (continued)

\begin{tabular}{|c|c|c|c|c|c|c|c|c|c|}
\hline \multirow{2}{*}{ Character } & \multirow[t]{2}{*}{$\mathrm{N}$} & \multicolumn{2}{|c|}{ Range } & \multicolumn{2}{|c|}{ Mean } & \multicolumn{2}{|c|}{ SD } & \multicolumn{2}{|c|}{ Holotype } \\
\hline & & $\mu \mathrm{m}$ & $p t$ & $\mu \mathrm{m}$ & pt & $\mu \mathrm{m}$ & $p t$ & $\mu \mathrm{m}$ & $p t$ \\
\hline External secondary branch & 24 & $12.9-20.2$ & $19.0-25.8$ & 17.3 & 22.0 & 1.7 & 1.8 & 17.5 & 21.6 \\
\hline External base/primary branch (cct) & 24 & $48.4-66.7$ & - & 56.5 & - & 4.6 & - & 52.8 & - \\
\hline Internal base & 27 & $7.4-14.6$ & $11.4-18.6$ & 11.4 & 14.5 & 1.9 & 1.9 & 10.6 & 13.1 \\
\hline Internal primary branch & 27 & $15.4-24.8$ & $22.9-29.9$ & 20.7 & 26.4 & 2.2 & 1.9 & 22.6 & 27.8 \\
\hline Internal secondary branch & 27 & $12.6-20.2$ & $17.2-25.1$ & 16.4 & 21.0 & 2.1 & 2.0 & 15.7 & 19.3 \\
\hline Internal base/primary branch (cct) & 27 & $43.5-65.8$ & - & 54.9 & - & 5.6 & - & 46.9 & - \\
\hline \multicolumn{10}{|c|}{ Claw II heights } \\
\hline External base & 28 & $8.6-16.2$ & $13.0-20.3$ & 12.7 & 16.2 & 1.8 & 1.7 & 15.0 & 18.5 \\
\hline External primary branch & 28 & $17.1-26.6$ & $23.8-33.7$ & 22.2 & 28.4 & 2.1 & 2.5 & 26.6 & 32.8 \\
\hline External secondary branch & 28 & $13.5-21.6$ & $18.0-27.8$ & 18.2 & 23.3 & 1.7 & 2.0 & 20.2 & 24.9 \\
\hline External base/primary branch (cct) & 28 & $47.9-74.2$ & - & 57.2 & - & 5.5 & - & 56.4 & - \\
\hline Internal base & 28 & $8.3-15.8$ & $12.5-19.9$ & 11.7 & 15.0 & 1.8 & 1.7 & 13.2 & 16.3 \\
\hline Internal primary branch & 28 & $15.4-25.3$ & $23.7-31.9$ & 21.2 & 27.3 & 2.3 & 2.1 & 25.3 & 31.2 \\
\hline Internal secondary branch & 28 & $11.7-20.5$ & $18.0-26.0$ & 16.9 & 21.7 & 2.0 & 2.0 & 20.5 & 25.2 \\
\hline Internal base/primary branch (cct) & 28 & $46.4-65.0$ & - & 55.0 & - & 5.3 & - & 52.2 & - \\
\hline \multicolumn{10}{|c|}{ Claw III heights } \\
\hline External base & 26 & $9.3-15.2$ & $13.5-18.8$ & 12.6 & 16.3 & 1.5 & 1.6 & 14.0 & 17.2 \\
\hline External primary branch & 26 & $16.9-26.3$ & $24.1-32.4$ & 22.3 & 28.8 & 2.3 & 2.4 & 26.3 & 32.4 \\
\hline External secondary branch & 26 & $12.1-21.1$ & $18.0-26.1$ & 17.9 & 23.1 & 1.9 & 2.0 & 21.1 & 26.0 \\
\hline External base/primary branch (cct) & 26 & $51.7-66.4$ & - & 56.5 & - & 3.7 & - & 53.2 & - \\
\hline Internal base & 24 & $9.0-15.0$ & $12.3-18.4$ & 11.8 & 15.1 & 1.6 & 1.7 & 13.3 & 16.4 \\
\hline Internal primary branch & 24 & $16.2-25.3$ & $23.3-32.6$ & 21.7 & 27.8 & 2.3 & 2.4 & 25.3 & 31.2 \\
\hline Internal secondary branch & 24 & $12.0-20.8$ & $17.9-27.1$ & 17.2 & 22.1 & 2.2 & 2.5 & 20.8 & 25.6 \\
\hline Internal base/primary branch (cct) & 24 & $47.1-64.4$ & - & 54.3 & - & 4.5 & - & 52.6 & - \\
\hline \multicolumn{10}{|c|}{ Claw IV heights } \\
\hline Anterior base & 23 & $10.6-18.3$ & $15.7-23.1$ & 14.4 & 18.6 & 1.8 & 1.8 & 15.3 & 18.8 \\
\hline Anterior primary branch & 23 & $21.5-31.8$ & $29.4-41.5$ & 27.4 & 35.4 & 2.8 & 2.9 & 29.0 & 35.7 \\
\hline Anterior secondary branch & 23 & $14.4-23.4$ & $19.8-31.5$ & 19.8 & 25.5 & 2.9 & 2.9 & 22.7 & 28.0 \\
\hline Anterior base/primary branch (cct) & 23 & $46.5-57.5$ & - & 52.5 & - & 2.9 & - & 52.8 & - \\
\hline Posterior base & 24 & $9.2-18.4$ & $14.1-23.2$ & 13.8 & 17.6 & 2.3 & 2.3 & 14.3 & 17.6 \\
\hline Posterior primary branch & 24 & $19.7-30.4$ & $28.7-39.0$ & 26.7 & 34.3 & 2.9 & 2.6 & 28.1 & 34.6 \\
\hline Posterior secondary branch & 24 & $13.9-24.1$ & $20.9-29.2$ & 19.3 & 24.8 & 2.6 & 2.6 & 22.1 & 27.2 \\
\hline Posterior base/primary branch (cct) & 24 & $43.6-63.9$ & - & 51.4 & - & 5.2 & - & 50.9 & - \\
\hline Number of teeth on external lunula III & 29 & $7-19$ & - & 12 & - & 3 & - & 10 & - \\
\hline Number of teeth on internal lunula III & 28 & $7-16$ & - & 11 & - & 2 & - & 10 & - \\
\hline Number of teeth on anterior lunula IV & 28 & $9-23$ & - & 14 & - & 3 & - & 13 & - \\
\hline Number of teeth on posterior lunula IV & 28 & $10-22$ & - & 14 & - & 3 & - & 17 & - \\
\hline
\end{tabular}


Body yellow, after fixation in Hoyer's medium, all specimens become transparent (Fig. 1A). Eyes present both in live animals and specimens mounted in Hoyer's medium. Body and leg cuticle without granulation (Figs 1A, 3A-D).

Claws slender, primary branches with distinct accessory points (Fig. 3A-D) and a system of internal septa as described by Lisi et al. (2020). Secondary branches approximately $80 \%$ of the length of the primary branches. An evident stalk system connecting the claws to the lunulae is visible under PCM and SEM (Fig. 3A-D). The stalk system consists of a thin laminar stalk connecting the claw to the lunula and two posterior lateral extensions (Fig. 3A-D). The distal tips of these lateral extension under PCM appear to be connected to the stalk where it contacts the lunula (Fig. 3A-B) whereas under SEM the stalk system is visible as a cuticular plate with a protuberant laminar stalk (Fig. 3C-D). Lunulae large, smoothly unified with the leg cuticle and with a crown of long, numerous and densely arranged spikes (2.0-3.1 $\mu \mathrm{m}$ long) (Fig. 3A-D). Lunulae I-III trapezoidal, whereas lunulae IV ovate (Fig. 2A-F). Divided cuticular bars, double muscle attachments, and horseshoe structures are visible in PCM (Fig. 3A-B).

Mouth antero-ventral. Sensory lobes merged into a single circular sensory field surrounding the mouth (Fig. 4A). Anteriorly, the mouth begins with fused peribuccal lamellae forming a circular velum/lamina which is posteriorly folded into a pre-mouth ventricle (Fig. 4A-B). With the exception of the second band of teeth, which is rarely and only faintly visible in larger specimens, the oral cavity armature is not visible under PCM. (Fig. 5B-C). Under SEM, the oral cavity armature is clearly seen to be composed of three bands of teeth (Fig. 4A-B). The first and the second band form continuous rings around the axis of the
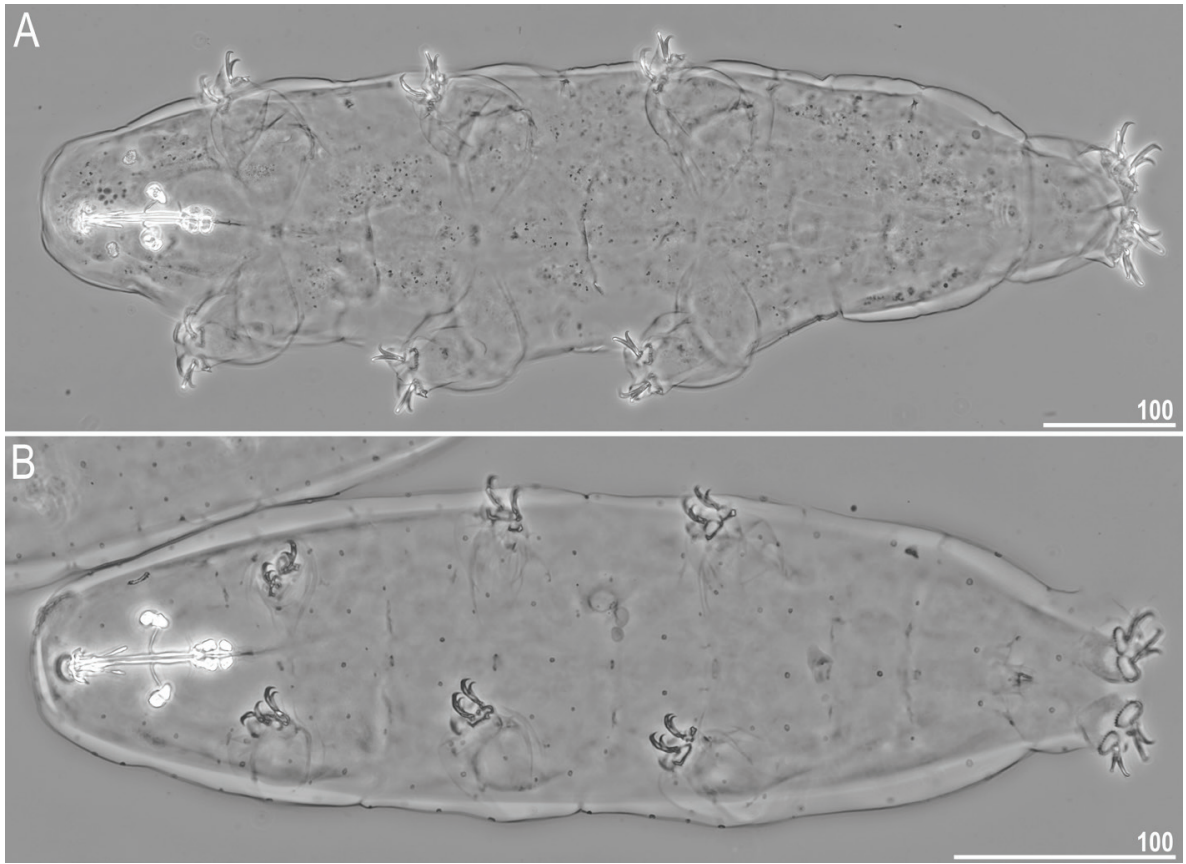

Fig. 1. Richtersius tertius sp. $\mathrm{n}$. habitus. $\mathrm{A}=$ adult, dorso-ventral projection (holotype, $\mathrm{PCM}$ ); $\mathrm{B}=$ hatchling, dorso-ventral projection (PCM). Scale bars in $\mu \mathrm{m}$ 
mouth, whereas the third band is divided into a dorsal and a ventral portion (Fig. 4A-B). The first band of teeth lies on the inner surface of the velum and is composed of numerous small granular cones forming about twenty irregular rows with slightly bigger teeth posi-

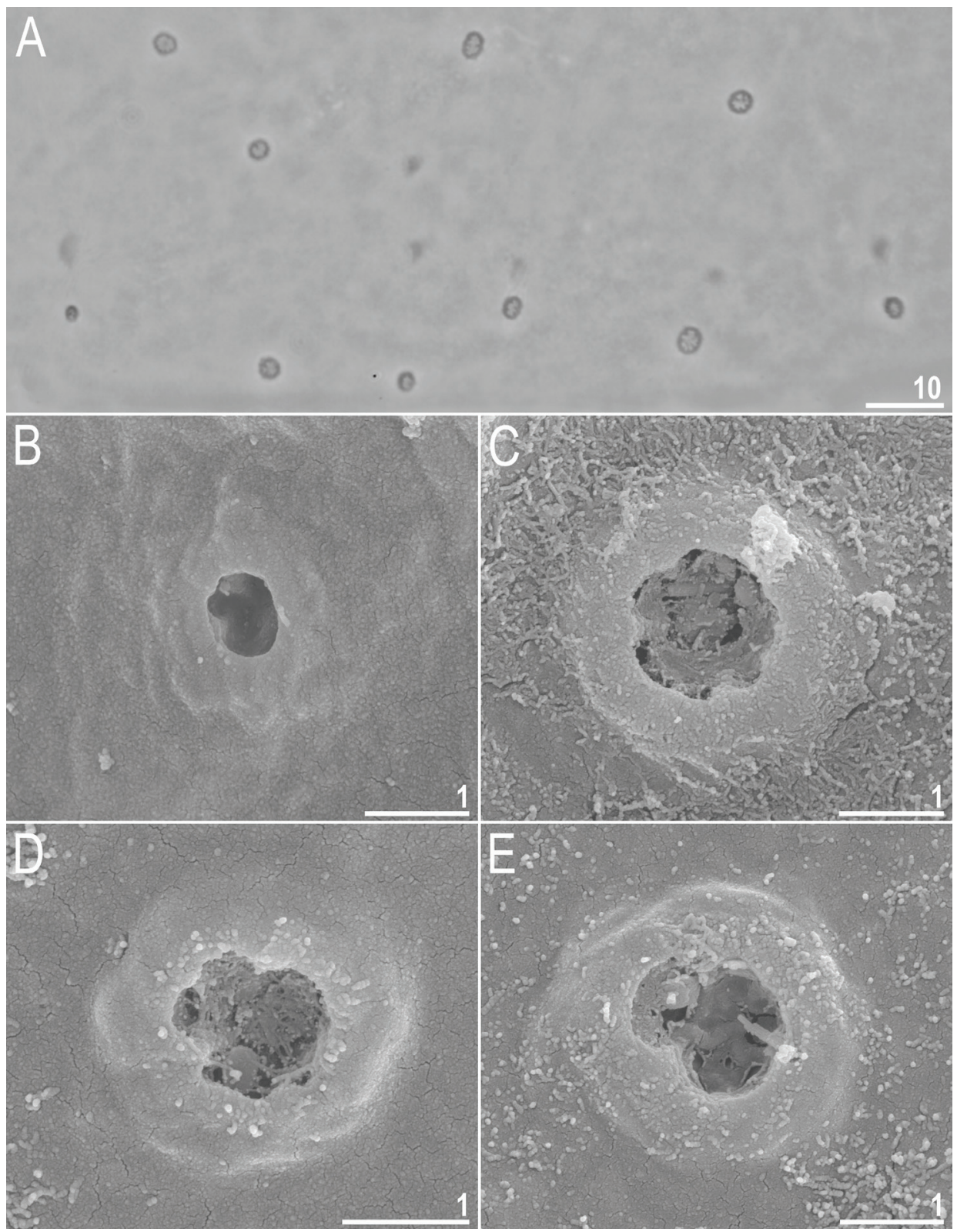

Fig. 2. Richtersius tertius sp. n. pores. $\mathrm{A}=$ pores on the hatchling dorsal cuticle $(\mathrm{PCM})$; $\mathrm{B}-\mathrm{E}=$ pores on the hatchling dorsal cuticle (SEM). Scale bars in $\mu \mathrm{m}$ 
tioned on the edge closest to the velum (Fig. 4A-B). The second band of teeth consists of about ten irregular rows of densely packed, elongate, sharp cones which lie on a cuticular fold protruding from the pre-mouth ventricle (Fig. 4A-B). The discontinuous third band of teeth is situated between the second band of teeth and buccal tube opening and is divided into a dorsal and a ventral portion, both in the form of a single large tooth, resembling a beak (Fig. 4A-B). The ventral tooth resembles an isosceles trapezium standing on its longer base, with a ragged upper edge. The dorsal tooth is semicircular in shape, with a crescentshaped indentation in its middle (Fig. 4 A-B).

Table 3. Measurements [in $\mu \mathrm{m}$ ] and $p t$ values of selected morphological structures of hatchlings of Richtersius tertius sp. n. (Specimens mounted in Hoyer's medium; $\mathrm{N}=$ number of specimen/structures measured, Range refers to the smallest and the largest structure among all measured specimens; $\mathrm{SD}$ = standard deviation).

\begin{tabular}{|c|c|c|c|c|c|c|c|}
\hline \multirow{2}{*}{ Character } & \multirow{2}{*}{$\mathrm{N}$} & \multicolumn{2}{|c|}{ Range } & \multicolumn{2}{|c|}{ Mean } & \multicolumn{2}{|c|}{ SD } \\
\hline & & $\mu \mathrm{m}$ & $p t$ & $\mu \mathrm{m}$ & $p t$ & $\mu \mathrm{m}$ & $p t$ \\
\hline Body length & 6 & $433-505$ & $738-922$ & 474 & 834 & 27 & 81 \\
\hline \multicolumn{8}{|c|}{ Buccal tube } \\
\hline Buccal tube length & 6 & $51.4-67.8$ & - & 57.3 & - & 7.6 & - \\
\hline Stylet support insertion point & 5 & $34.4-46.3$ & $66.8-68.3$ & 39.1 & 67.7 & 6.1 & 0.7 \\
\hline Buccal tube external width & 6 & $3.6-5.6$ & $6.5-10.9$ & 4.6 & 8.1 & 0.7 & 1.6 \\
\hline Buccal tube internal width & 6 & $1.5-1.8$ & $2.7-3.1$ & 1.7 & 2.9 & 0.1 & 0.2 \\
\hline Ventral lamina length & 5 & $21.5-32.1$ & $41.8-47.3$ & 26.2 & 45.2 & 5.0 & 2.3 \\
\hline \multicolumn{8}{|c|}{ Placoid lengths } \\
\hline Macroplacoid 1 & 6 & $11.0-12.4$ & $18.3-22.3$ & 11.6 & 20.4 & 0.6 & 1.8 \\
\hline Macroplacoid 2 & 6 & $5.1-6.9$ & $9.9-13.2$ & 6.5 & 11.4 & 0.7 & 1.6 \\
\hline Macroplacoid row & 6 & 17.3-19.5 & $28.6-35.8$ & 18.6 & 32.7 & 0.8 & 3.0 \\
\hline \multicolumn{8}{|c|}{ Claw I heights } \\
\hline External base & 4 & $7.6-9.1$ & $13.8-17.7$ & 8.5 & 16.2 & 0.6 & 1.7 \\
\hline External primary branch & 4 & $14.2-15.5$ & $27.2-29.9$ & 14.9 & 28.4 & 0.5 & 1.2 \\
\hline External secondary branch & 4 & $10.7-11.8$ & $20.6-22.1$ & 11.2 & 21.3 & 0.5 & 0.6 \\
\hline External base/primary branch (cct) & 4 & $50.7-64.1$ & - & 57.3 & - & 5.6 & - \\
\hline Internal base & 5 & $7.2-8.7$ & 11.0-15.2 & 7.8 & 13.7 & 0.6 & 1.8 \\
\hline Internal primary branch & 5 & $12.9-16.8$ & $22.4-28.7$ & 14.6 & 25.5 & 1.5 & 2.3 \\
\hline Internal secondary branch & 5 & $9.1-12.8$ & $16.9-22.7$ & 11.2 & 19.6 & 1.3 & 2.5 \\
\hline Internal base/primary branch (cct) & 5 & $49.3-57.4$ & - & 53.5 & - & 3.2 & - \\
\hline \multicolumn{8}{|c|}{ Claw II heights } \\
\hline External base & 6 & $8.0-9.3$ & $12.1-16.9$ & 8.6 & 15.2 & 0.5 & 1.9 \\
\hline External primary branch & 6 & $14.1-16.6$ & $21.3-32.0$ & 15.2 & 26.9 & 1.0 & 3.8 \\
\hline External secondary branch & 6 & $11.0-12.9$ & $16.6-24.7$ & 11.8 & 20.9 & 0.9 & 2.8 \\
\hline External base/primary branch (cct) & 6 & $52.4-60.4$ & - & 56.7 & - & 3.0 & - \\
\hline
\end{tabular}


Table 3 (continued)

\begin{tabular}{|c|c|c|c|c|c|c|c|}
\hline \multirow{2}{*}{ Character } & \multirow{2}{*}{$\mathrm{N}$} & \multicolumn{2}{|c|}{ Range } & \multicolumn{2}{|c|}{ Mean } & \multicolumn{2}{|c|}{ SD } \\
\hline & & $\mu \mathrm{m}$ & $p t$ & $\mu \mathrm{m}$ & pt & $\mu \mathrm{m}$ & pt \\
\hline Internal base & 6 & $7.5-8.3$ & $11.1-16.0$ & 7.8 & 13.7 & 0.3 & 1.9 \\
\hline Internal primary branch & 6 & $13.2-14.4$ & $20.4-27.8$ & 14.0 & 24.7 & 0.5 & 3.1 \\
\hline Internal secondary branch & 6 & $9.7-12.1$ & $15.3-23.3$ & 11.1 & 19.6 & 1.0 & 2.9 \\
\hline Internal base/primary branch (cct) & 6 & $52.1-62.9$ & - & 55.7 & - & 4.2 & - \\
\hline \multicolumn{8}{|c|}{ Claw III heights } \\
\hline External base & 5 & $8.0-9.7$ & $14.0-17.6$ & 9.0 & 16.3 & 0.7 & 1.5 \\
\hline External primary branch & 5 & $14.6-16.9$ & $24.9-31.6$ & 15.6 & 28.3 & 1.0 & 2.4 \\
\hline External secondary branch & 5 & $9.8-13.7$ & $19.1-23.1$ & 11.5 & 20.8 & 1.5 & 1.5 \\
\hline External base/primary branch (cct) & 5 & $54.8-63.8$ & - & 57.8 & - & 3.8 & - \\
\hline Internal base & 5 & $6.8-8.6$ & $12.7-16.4$ & 8.0 & 14.5 & 0.8 & 1.5 \\
\hline Internal primary branch & 5 & $13.8-16.3$ & $24.0-28.2$ & 14.7 & 26.6 & 0.9 & 1.6 \\
\hline Internal secondary branch & 5 & $9.4-13.6$ & $18.3-21.0$ & 10.9 & 19.7 & 1.7 & 1.2 \\
\hline Internal base/primary branch (cct) & 5 & $49.3-59.0$ & - & 54.4 & - & 4.0 & - \\
\hline \multicolumn{8}{|c|}{ Claw IV heights } \\
\hline Anterior base & 3 & $8.5-11.5$ & $16.3-17.0$ & 9.7 & 16.6 & 1.6 & 0.3 \\
\hline Anterior primary branch & 3 & $18.4-21.0$ & $31.0-37.1$ & 19.5 & 33.8 & 1.3 & 3.1 \\
\hline Anterior secondary branch & 3 & 13.0-15.6 & $23.0-25.4$ & 13.9 & 24.0 & 1.5 & 1.3 \\
\hline Anterior base/primary branch (cct) & 3 & $44.5-54.8$ & - & 49.4 & - & 5.1 & - \\
\hline Posterior base & 5 & $7.7-10.8$ & $15.0-15.9$ & 8.6 & 15.4 & 1.3 & 0.4 \\
\hline Posterior primary branch & 5 & $16.3-22.6$ & $31.7-34.1$ & 18.5 & 33.3 & 2.4 & 0.9 \\
\hline Posterior secondary branch & 5 & $11.6-16.9$ & $22.6-28.5$ & 13.6 & 24.5 & 2.2 & 2.4 \\
\hline Posterior base/primary branch (cct) & 5 & $44.5-47.9$ & - & 46.3 & - & 1.5 & - \\
\hline Number of teeth on external lunula III & 6 & $10-15$ & - & 12 & - & 2 & - \\
\hline Number of teeth on internal lunula III & 6 & $7-15$ & - & 13 & - & 3 & - \\
\hline Number of teeth on anterior lunula IV & 5 & $11-16$ & - & 13 & - & 2 & - \\
\hline Number of teeth on posterior lunula IV & 6 & $11-18$ & - & 14 & - & 2 & - \\
\hline Pore density & 6 & $3-6$ & - & 5 & - & 1 & - \\
\hline Pore size & 6 & $1.2-4.1$ & - & 2.8 & - & 0.6 & - \\
\hline
\end{tabular}

Buccal apparatus massive. The oral cavity is followed by a system of massive apophyses forming a buccal crown (Fig. 5A-C). Anteriorly, the system consists of dorso-lateral and ventro-lateral triangular apophyses (Fig. 5A, C). The dorsal and ventral apophyses, are composed of anteriorly positioned large cuticular hooks followed by longitudinal crests which in case of ventral apophyses might be homologous to the ventral lamina found in ordinary macrobiotids (Fig. 5B). The hook in the ventral apophyses is smaller than the dorsal 
hook (Fig. 5B). The buccal tube wall exhibits variable thickness, but the internal diameter of the buccal tube is almost uniformly narrow (Fig. 5A). From mouth opening to the stylet support insertion point, the thickens of the buccal tube wall increases only slightly before also slightly expanding to its greatest thickness beyond this point before then shrink posteriorly (Fig. 5A). Pharynx spherical, with bilobed apophyses, three anterior cuticular spikes (typically only two are visible in any given plane) and two granular macroplacoids $(2<1)$. The first and the second macroplacoid with a faint constriction positioned centrally and subterminally, respectively (Fig. 5A-E).

Hatchlings (measurements and statistics in Table 3). Same as adults, except for smaller body size (Fig. 1B) and round pores (1.2-4.1 $\mu \mathrm{m}$ in diameter) with wavy edges, clearly visible both under PCM and SEM, scattered randomly on the entire body cuticle (Figs 1B, 2A-E), with a PD range of 3-6.
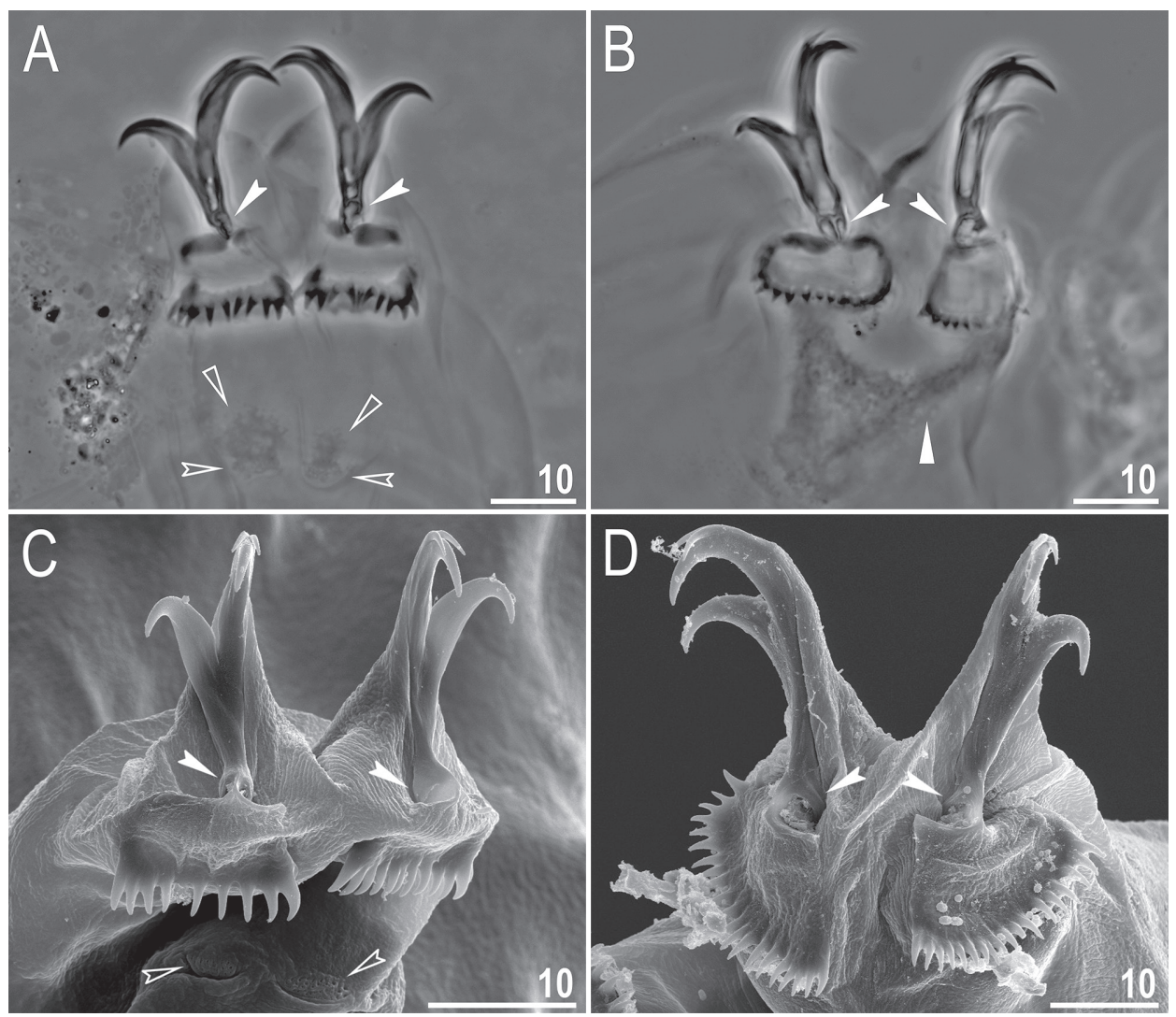

Fig. 3. Richtersius tertius sp. n. claws. A-B = claws II and IV (PCM); C-D = claws III and IV (SEM). Filled indented arrowheads indicate lateral expansions positioned posteriorly to the laminar stalk connecting the claw to the lunula, empty indented arrowheads indicate the double muscle attachments under the claws, empty flat arrowheads indicate the divided cuticular bar, filled flat arrowhead indicates the horseshoe structure connecting the anterior and posterior claws. Scale bars in $\mu \mathrm{m}$ 
Table 4. Measurements [in $\mu \mathrm{m}$ ] of the eggs of Richtersius tertius sp. n. (eggs mounted in Hoyer's medium; process base/height ratio is expressed as percentage; $\mathrm{N}=$ number of eggs/structures measured; Range refers to the smallest and the largest structure among all measured specimens; $\mathrm{SD}=$ standard deviation).

\begin{tabular}{lcccc}
\hline Character & N & Range & Mean & SD \\
\hline Egg bare diameter & 30 & $117.4-155.3$ & 139.2 & 7.9 \\
Egg full diameter & 30 & $149.8-188.2$ & 165.9 & 10.1 \\
Process height & 90 & $13.7-27.4$ & 20.0 & 2.9 \\
Process base width & 90 & $3.0-6.5$ & 4.7 & 0.9 \\
Process base/height ratio (\%) & 90 & $14-42$ & 24 & 5 \\
Inter-process distance & 90 & $5.2-13.1$ & 8.3 & 1.7 \\
Number of processes on the egg circumference & 30 & $32-44$ & 38.0 & 3.5 \\
\hline
\end{tabular}

Eggs (measurements and statistics in Table 4). Large, oval, light yellow, laid freely (Figs 6A-B, 7A). The surface between processes is smooth but with refracting dots faintly visible only under PCM, but difficult to observe because of the amount of debris that is typically attached to the egg surface (Figs 6C, 7A-D). Processes in the shape of elongated, thin, cones with a ragged surface (Figs 6 D-E, 7B-D). Terminal portions of the egg processes are flexible, sometimes divided into two or three short filaments (Figs 6D-E, 7A-D). Terminal discs or spatulas absent.

Reproduction - The new species is dioecious: both males with testes and females with ovaries were recorded within the examined population (STEC et al. 2020a).
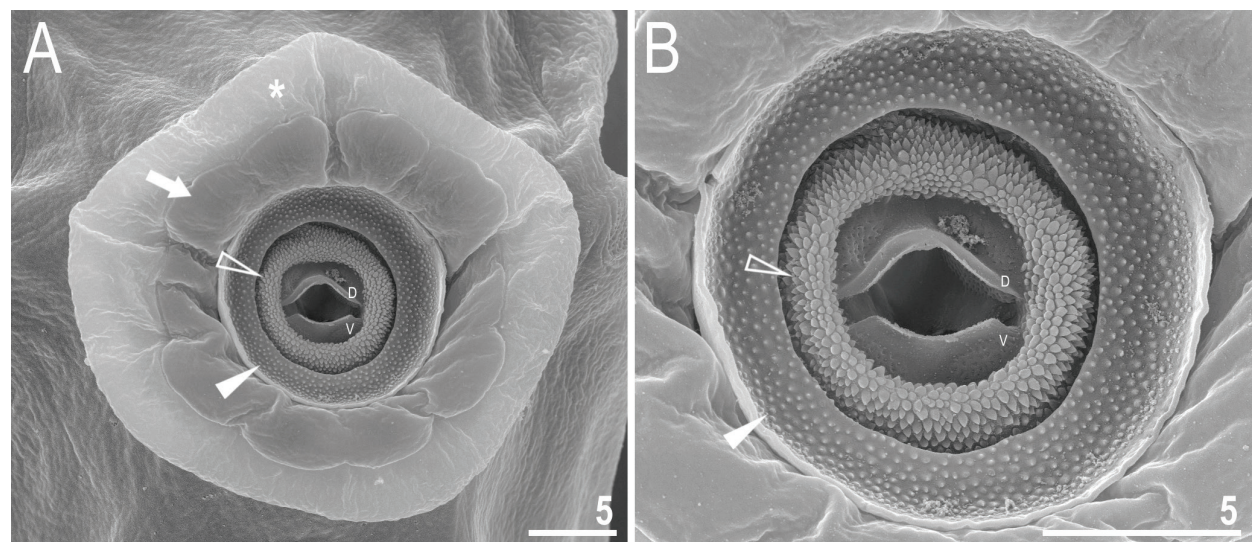

Fig. 4. Richtersius tertius sp. n. mouth opening with peribuccal structures and oral cavity armature of an adult (SEM). $\mathrm{A}=$ general view of the mouth opening; $\mathrm{B}=$ details of the oral cavity armature. Asterisk indicates the circular sensory field, filled arrow indicates the divided peribuccal velum/lamina, filled flat arrowheads indicate the first band of teeth, empty flat arrowheads indicate the teeth of the second band, dorsal and ventral teeth of third band are marked with $\mathrm{D}$ and $\mathrm{V}$, respectively. Scale bars in $\mu \mathrm{m}$ 
DNA sequences - The DNA sequences of four molecular markers (18S rRNA, 28S rRNA, ITS-2 and COI) associated with the species description have been previously published by STEс et al. (2020a). The respective GenBank accession numbers are given in Table 1.
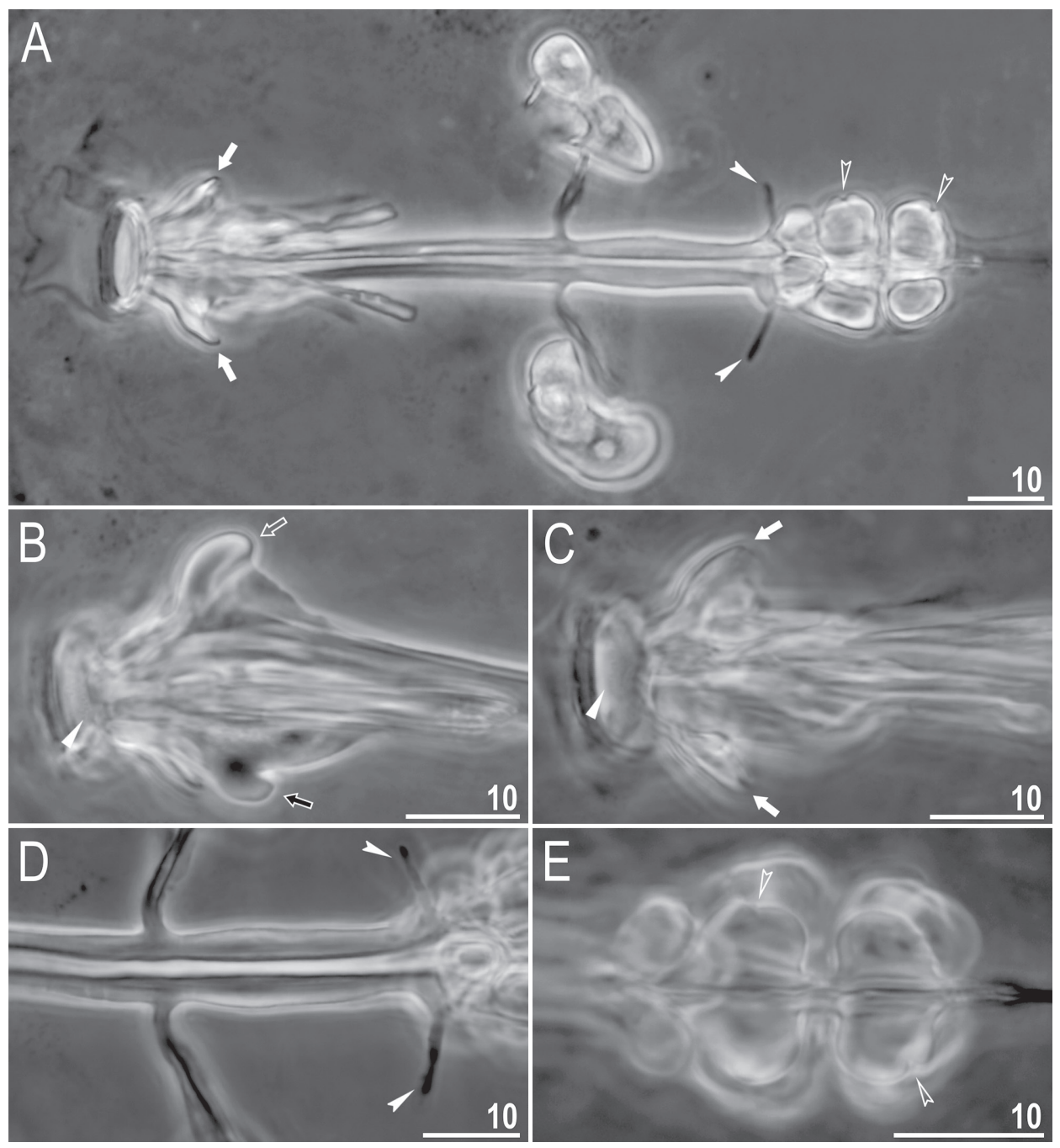

Fig. 5. Richtersius tertius sp. $\mathrm{n}$. buccal apparatus (PCM). A = dorsal projection of the entire buccal apparatus; $\mathrm{B}=$ later view of the buccal crown; $\mathrm{C}=$ ventral view of the buccal crown; $\mathrm{D}=$ stylet support insertion point of the buccal apparatus; $\mathrm{E}=$ macroplacoid morphology visible in ventral view. Filled arrows indicate the ventro-lateral triangular apophysis, filled indented arrowheads indicate dorsal spikes, empty indented arrowheads indicate constrictions in the macroplacoids, the empty arrow indicates the cuticular hook on the dorsal apophysis, the black filled arrow indicates the cuticular hook on the ventral apophysis, filled flat arrowheads indicate the second band of teeth in the oral cavity. Scale bars in $\mu \mathrm{m}$ 
Locality: $35^{\circ} 16^{\prime} 16^{\prime \prime} \mathrm{N}, 2^{\circ} 57^{\prime} 41^{\prime \prime} \mathrm{E}$; Greece, Crete, Chania, Omalos; forest; moss and lichen from a tree in a forest; coll. 04.07.2015 by Małgorzata Mitan and Małgorzata Osielczak.

Type depositories: The holotype (slide GR.008.15 with 4 paratypes), as well as 162 paratypes (slides: GR.008.*, where the asterisk can be substituted by any of the following numbers, 03-29; SEM stub: 19.12) and 73 eggs (slides: GR.008.* 30-33; SEM stub: 19.12) are deposited at the Institute of Zoology and Biomedical Research, Jagiellonian University, Gronostajowa 9, 30-387, Kraków, Poland whereas 51 paratypes (slides: GR.008.*, where the asterisk can be substituted by any of the following numbers, 20-29) and 31 eggs (slides: GR.008.* 34-37) are deposited at the Institute of Systematics and Evolution of Animals, Polish Academy of Sciences, Sławkowska 17, 31-016, Kraków, Poland.
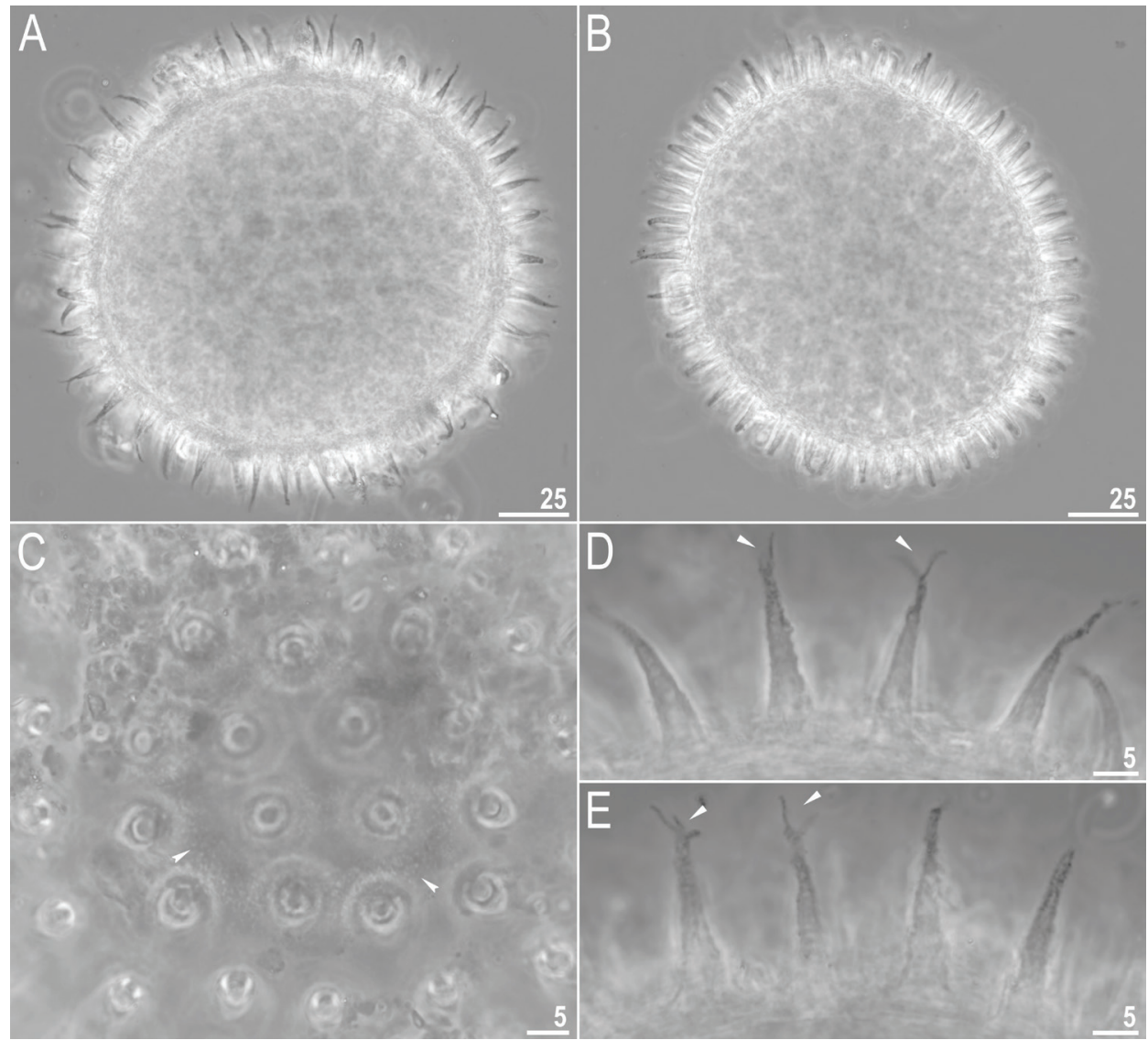

Fig. 6. Richtersius tertius sp. n. egg chorion morphology (PCM). A-B = egg midsection under 400× magnification; $C=$ egg surface under $1000 \times$ magnification; $D-E=$ egg processes midsection under 1000× magnification. Filled flat arrowheads indicate flexible terminal portion of the egg process, filled indented arrowheads indicate the refracting dots covering the egg surface between processes (in the majority of eggs this character is not visible as the egg surface is often covered by dirt). Scale bars in $\mu \mathrm{m}$ 


\section{DISCUSSION}

Phenotypic differential diagnosis

As mentioned above, the genus Richtersius, currently comprises only two species, $R$. coronifer, known only from Norway and Greenland (STEC et al. 2020a), and R. ziemowiti, known only from Nepal (Kayastha et al. 2020a,b). The new species differs from:

Richtersius coronifer by: the shape and size of cuticular pores (round pores, $1.2-4.1 \mu \mathrm{m}$ in diameter, with wavy edges in $R$. tertius sp. n. vs round and oval pores, $0.35-0.69 \mu \mathrm{m}$ in diameter, with smooth edges in $R$. coronifer), a lower PD (3-6 in the new species vs 60-88 in R. coronifer), a weakly developed thickness of the buccal tube wall posterior to the stylet support insertion point (the thickness well developed and obvious in $R$. coronifer), a more anteriorly positioned
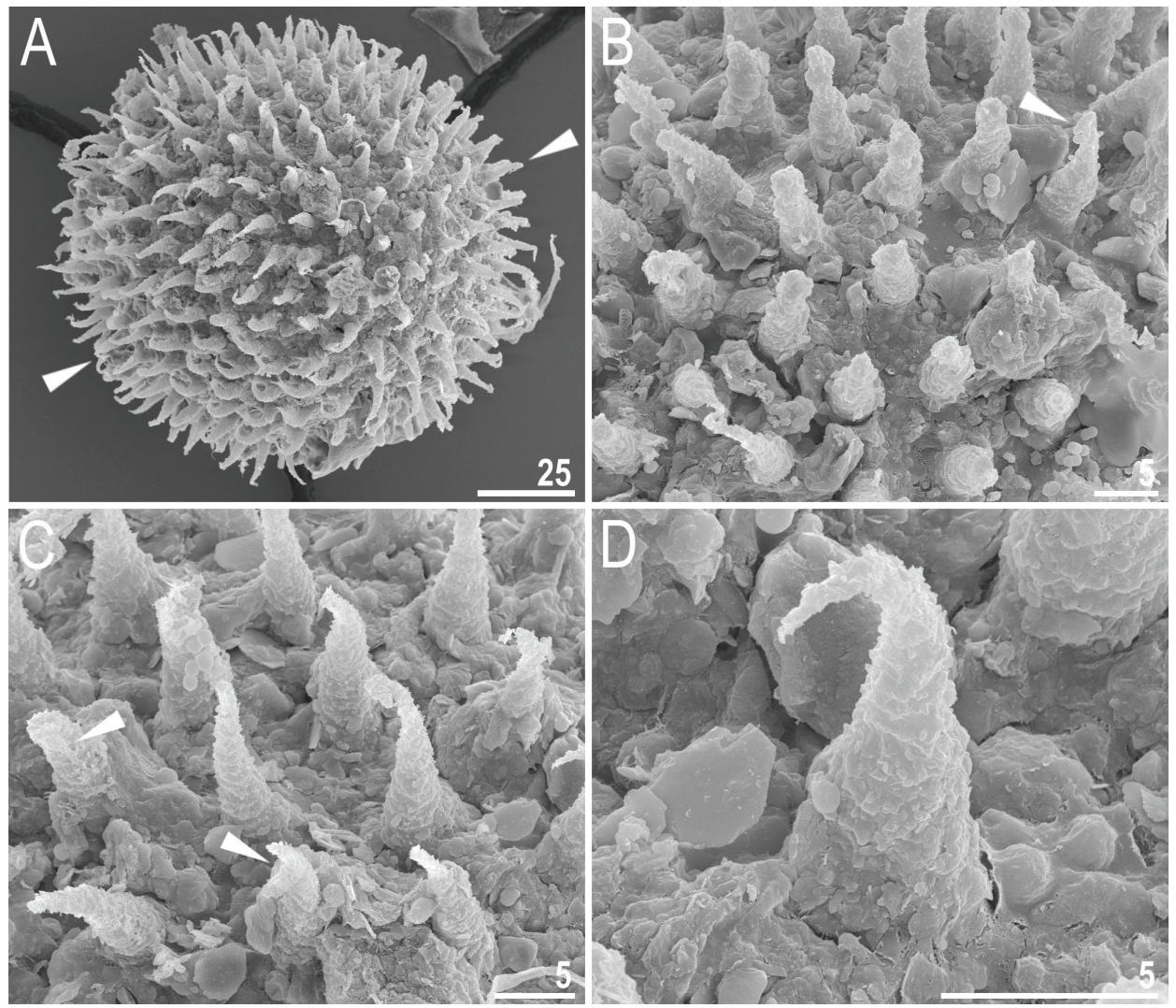

Fig. 7. Richtersius tertius sp. n. egg chorion morphology (SEM). A - entire egg; B-C = Details of egg surface and processes; $\mathrm{D}=$ magnification of the egg process. Filled flat arrowheads indicate the flexible terminal portion of the egg process. Scale bars in $\mu \mathrm{m}$ 
stylet support insertion point ( $p t=65.3-68.9$ in the new species $v s p t=72.1-75.6$ in $R$. coronifer), the morphology of the egg surface seen in PCM (with refracting dots in the new species vs smooth without refracting dots in $R$. coronifer), a smaller number of processes on the egg circumference (32-44 in $R$. tertius sp. n. vs 60-77 in $R$. coronifer), a smaller egg bare diameter $(117.4-155.3 \mu \mathrm{m}$ in the new species vs 173.2-233.4 $\mu \mathrm{m}$ in $R$. coronifer), and a smaller egg full diameter (149.8-188.2 $\mu \mathrm{m}$ in the new species vs 201.5-263.7 $\mu \mathrm{m}$ in R. coronifer).

Richtersius ziemowiti by: the shape of cuticular pores (round pores with wavy edges in $R$. tertius sp. n. vs round and oval pores with smooth margins in $R$. ziemowiti), a lower PD (3-6 in the new species vs 20-24 in R. ziemowiti), the morphology of the egg surface seen in PCM (with refracting dots in the new species $v s$ without refracting dots in $R$. ziemowiti), a more anteriorly positioned stylet support insertion point $(p t=65.3-68.9$ in the new species $v s p t=73.3-80.7$ in $R$. ziemowiti), and a slightly lower $p t$ value for external primary branches of claws I ( $p t=23.8-31.6$ in the news species vs $p t=33.2-42.9$ in $R$. ziemowiti).

\section{Genetic comparison}

The ranges of uncorrected genetic p-distances between Richtersius tertius sp. n. and genotyped populations/species of the genus Richtersius are as follows: - $\quad 18$ rRNA: $0.4-2.2 \%$ ( $0.9 \%$ on average), with the most similar being $R$. aff. coronifer from Italy and Poland (MH681762, MK211387), R. aff. coronifer (HQ604987-8, KT778706-7) from Italy, R. cf. coronifer (KT778711) from Italy and the least similar being $R$. aff. coronifer (EU266931) from Greenland;

- $\quad 28$ rRNA: $0.3-2.3 \%$ (1.6\% on average), with the most similar being $R$. aff. coronifer from Italy (MK211385) and the least similar being $R$. aff. coronifer from Norway and R. ziemowiti (MH681757, MT241893) from Nepal;

- $\quad$ ITS-2: 7.7-35.6\% (17.7\% on average), with the most similar being $R$. aff. coronifer from Italy (MK211382, MK211383) and the least similar being $R$. coronifer s.s. from Norway (MH681763);

- COI: $16.8-25.3 \%$ (21\% on average), with the most similar being $R$. aff. coronifer from Italy (MK214327) and the least similar being Richtersius sp. (GU339056) from China.

\section{CONCLUSIONS}

Thanks to morphological and morphometric analysis, as well as integration of these data with the DNA sequences published previously, we described a new Richtersius species that constitute the third formally named species in the genus. According to STEC et al. (2020a) and KaYAstha et al. (2020a) there are at 
least six additional putative new Richtersius species awaiting description. We believe that the implementation of integrative taxonomic tools and the collection of extensive sets of morphological and morphometric data, linked to molecular markers, will allow delimitations of further species within the genus.

Acknowledgements - We are especially grateful to our colleagues Małgorzata Mitan and Małgorzata Osielczak for collecting sample which enabled us to conduct this study and to Brian Blagden, Łukasz Michalczyk as well as two anonymous reviewers for English improvements, suggestions and critical reading of our manuscript. During this study, DS was supported by the Foundation for Polish Science (FNP). The study was supported by the grant from the European Commission's programme "Transnational Access to Major Research Infrastructures" to SYNTHESYS (grant no. DK-TAF-2693 to DS) and by the Sonata Bis programme of the Polish National Science Centre (grant no. 2016/22/E/NZ8/00417 to Łukasz Michalczyk).

\section{REFERENCES}

Bertolani, R., Guidetti, R., Marchioro, T., Altiero, T., Rebecchi, L. \& Cesari, M. (2014): Phylogeny of Eutardigrada: New molecular data and their morphological support lead to the identification of new evolutionary lineages. - Molecular Phylogenetics and Evolution 76: 110-126. https://doi.org/10.1016/j.ympev.2014.03.006

Campbell, L. I., Rota-Stabelli, O., Marchioro, T., Longhorn, S. J., Edgecombe, G. E., Philippe, H., Telford, M. J., Rebecchi, L., Peterson, K. J. \& Pisani, D. (2011): MicroRNAs and phylogenomics resolve the phylogenetic relationships of the Tardigrada and suggest the velvet worms as the sister group of Arthropoda. - Proceedings of the National Academy of Sciences 108(38): 15920-15924.

https://doi.org/10.1073/pnas.1105499108

Czechowski, P., Sands, C. J., Adams, B. J., D’Haese, C. A., Gibson, J. A. E., McInnes, S. J. \& Stevens, M. I. (2012): Antarctic Tardigrada: a first step in understanding molecular operational taxonomic units (MOTUs) and biogeography of cryptic meiofauna. - Invertebrate Systematics 26(6): 526-538. https://doi.org/10.1071/IS12034

Dastych, H. (1980): Niesporczaki (Tardigrada) Tatrzańskiego Parku Narodowego. Vol. 9. - Monografie Fauny Polski, Warsaw, Cracow, 232 pp.

Degma, P. \& Guidetti, R. (2007): Notes to the current checklist of Tardigrada. - Zootaxa 1579: 41-53. https://doi.org/10.11646/zootaxa.1579.1.2

Degma, P., Bertolani, R. \& Guidetti, R. (2021): Actual checklist of Tardigrada species (2009-2021, 40th ed.). https://doi.org/10.25431/11380_1178608

Doyère, P. L. N. (1840): Memoire sur les Tardigrades. - Annales des Sciences Naturelles 2(14): 269-362.

Faurby, S., Jonsson, K. I., Rebecchi, L. \& Funch, P. (2008): Variation in anhydrobiotic survival of two eutardigrade morphospecies: a story of cryptic species and their dispersal. - Journal of Zoology 275(2): 139-145. https://doi.org/10.1111/j.1469-7998.2008.00420.x

Guidetti, R. \& Bertolani, R. (2005): Tardigrade taxonomy: an updated check list of the taxa and a list of characters for their identification. - Zootaxa 845: 1-46. https://doi.org/10.11646/zootaxa.845.1.1 
Guidetti, R., Gandolfi, A., Rossi, V. \& Bertolani, R. (2005): Phylogenetic analysis of Macrobiotidae (Eutardigrada, Parachela): a combined morphological and molecular approach. - Zoologica Scripta 34: 235-244. https://doi.org/10.1111/j.1463-6409.2005.00193.x

Guidetti, R., Rebecchi, L., Bertolani, R., Jönsson, K. I., Kristensen, R. M. \& Cesari, M. (2016): Morphological and molecular analyses on Richtersius (Eutardigrada) diversity reveal its new systematic position and lead to the establishment of a new genus and a new family within Macrobiotoidea. - Zoological Journal of the Linnean Society 178(4): 834-845. https://doi.org/10.1111/zoj.12428

Guidetti, R., Schill, R. O., Giovannini, I., Massa, E., Goldoni, S. E., Ebel, C., Förschler, M. I., Rebecchi L. \& Cesari, M. (2021): When DNA sequence data and morphological results fit together: Phylogenetic position of Crenubiotus within Macrobiotoidea (Eutardigrada) with description of Crenubiotus ruhesteini sp. nov. - Journal of Zoological Systematics and Evolutionary Research 59: 576-587. https://doi.org/10.1111/jzs.12449

Jorgensen, A. \& Kristensen, R. M. (2004): Molecular phylogeny of Tardigrada - investigation of the monophyly of Heterotardigrada. - Molecular Phylogenetics and Evolution 32: 666-670. https://doi.org/10.1016/j.ympev.2004.04.017

KaczmareK, Ł. \& MichalczyK, Ł. (2017): The Macrobiotus hufelandi (Tardigrada) group revisited. - Zootaxa 4363(1): 101-123. https://doi.org/10.11646/zootaxa.4363.1.4

KaczmareK, Ł, MichalczyK, Ł. \& McInnes, S. J. (2015): Annotated zoogeography of non-marine Tardigrada. Part II: South America. - Zootaxa 3923(1): 1-107. https://doi.org/10.11646/zootaxa.3923.1.1

KaczmareK, Ł., MichalczyK, Ł. \& McInnes, S. J. (2016): Annotated zoogeography of nonmarine Tardigrada. Part III: North America and Greenland. - Zootaxa 4203(1): 1-249. https://doi.org/10.11646/zootaxa.4203.1.1

Kaczmarek, Ł., Cytan, J., Zawierucha, K., Diduszko, D. \& MichalczyK, Ł. (2014): Tardigrades from Peru (South America), with descriptions of three new species of Parachela. - Zootaxa 3790(2): 357-379. https://doi.org/10.11646/zootaxa.3790.2.5

КАтон, K. \& Тон, Н. (2008): Recent developments in the MAFFT multiple sequence alignment program. - Briefings in Bioinformatics 9: 286-298. https://doi.org/10.1093/bib/bbn013

Katoh, K., Misawa, K., Kuma, K., Miyata, T. (2002): MAFFT: a novel method for rapid multiple sequence alignment based on fast Fourier transform. - Nucleic Acids Research 30: 3059-3066. https://doi.org/10.1093/nar/gkf436

Kayastha, P., Berdi, D., Mioduchowska, M., Gawlak, M., Łukasiewicz, A., Gołdyn, B. \& KACZMAREK, Ł. (2020b): Some tardigrades from Nepal (Asia) with integrative description of Macrobiotus wandae sp. nov. (Macrobiotidae: hufelandi group). - Annales Zoologici 70(1): 121-142. https://doi.org/10.3161/00034541ANZ2020.70.1.007

Kayastha, P., Berdi, D., Mioduchowska, M., Gawlak, M., Łukasiewicz, A., GoŁdyn, B., JęDrZejewski, S. \& KaczMAReK, Ł. (2020a): Description and molecular characterization of Richtersius ziemowiti sp. nov. (Richtersiidae) from Nepal (Asia) with evidence of heterozygous point mutation events in the $28 \mathrm{~S}$ rRNA. - Annales Zoologici 70(3): 381-396. https://doi.org/10.3161/00034541ANZ2020.70.3.010

Kiosya, Y., Pogwizd, J., Matsko, Y., Vecchi, M. \& Stec, D. (2021): Phylogenetic position of two Macrobiotus species with a revisional note on Macrobiotus sottilei Pilato, Kiosya, Lisi \& Sabella, 2012 (Tardigrada: Eutardigrada: Macrobiotidae). - Zootaxa 4933(1): 113-135. https://doi.org/10.11646/zootaxa.4933.1.5

KosztyŁa, P., Stec, D., Morek, W., Gąsiorek, P., Zawierucha, K., Michno, K., Ufir, K., MaŁek, D., Hlebowicz, K., Laska, A., Dudziak, M., Frohme, M., Prokop, Z. M., KaCZMAREK, Ł. \& MichalCZYK, Ł. (2016): Experimental taxonomy confirms the environmental stability of morphometric traits in a taxonomically challenging group 
of microinvertebrates. - Zoological Journal of the Linnean Society 178(4): 765-775. https://doi.org/10.1111/zoj.12409

Kumar, S. Stecher, G. \& Tamura, K. (2016): MEGA7: Molecular Evolutionary Genetics Analysis. Version 7.0 for Bigger Datasets. - Molecular Biology and Evolution 33: 18701874. https://doi.org/10.1093/molbev/msw054

Lisi, O., Londoño, R. \& Quiroga, S. (2020): Description of a new genus and species (Eutardigrada: Richtersiidae) from Colombia, with comments on the family Richtersiidae. - Zootaxa 4822(4): 531-550. https://doi.org/10.11646/zootaxa.4822.4.4

Maucci, W. \& Ramazzotti, G. (1981): Adorybiotus gen. nov.: nouva posizione sistematica per Macrobiotus granulatus Richters, 1903 e per Macrobiotus coronifer Richters, 1903 (Tardigrada, Macrobiotidae). - Memorie 'ell'Istituto Italiano di Idrobiologia 39: 153-159.

McInNes, S. J. (1994): Zoogeographic distribution of terrestrial/freshwater tardigrades from current literature. - Journal of Natural History 28: 257-352. https://doi.org/10.1080/00222939400770131

McInnes, S. J., MichalczyK, Ł. \& KaczmareK, Ł. (2017): Annotated zoogeography of nonmarine Tardigrada. Part IV: Africa. - Zootaxa 4284(1): 1-74.

https://doi.org/10.11646/zootaxa.4284.1.1

MichalczyK, Ł. \& KaczmareK, Ł. (2013): The Tardigrada register: a comprehensive online data repository for tardigrade taxonomy. - Journal of Limnology 72(S1): 175-181. https://doi.org/10.4081/jlimnol.2013.s1.e22

Morek, W., Stec, D., Gąsiorek, P., Schill, R. O., KaczmareK, Ł. \& MichalczyK, Ł. (2016): An experimental test of eutardigrade preparation methods for light microscopy. - Zoological Journal of the Linnean Society 178(4): 785-793. https://doi.org/10.1111/zoj.12457

Murray, J. (1911) Arctiscoida. - Proceedings of the Royal Irish Academy 31: 1-16.

Nelson, D. R., Guidetti, R. \& Rebecchi, L. (2015): Phylum Tardigrada. - Ecology and General Biology. 1(17): 347-380. https://doi.org/10.1016/B978-0-12-385026-3.00017-6

Pilato, G. \& Binda, M. G. (1989): Richtersius, nuove nenericrico in sostituzione di Richtersia Pilato e Binda, 1987 (Eutardigrada). - Animalia 16:147-148.

Pilato, G. (1981): Analisi di nuovi caratteri nello studio degli Eutardigradi. - Animalia 8: 51-57.

Rebecchi, L., Rossi, V., Altiero, T., Bertolani, R. \& Menozzi, P. (2003): Reproductive modes and genetic polymorphism in the tardigrade Richtersius coronifer (Eutardigrada, Macrobiotidae). - Invertebrate Biology 122: 19-27.

https://doi.org/10.1111/j.1744-7410.2003.tb00069.x

Richters F. (1903): Nordische Tardigraden. - Zoologischer Anzeiger 27: 168-172.

Richters F. (1904): Arktische Tardigraden. - Fauna Arctica 3: 494-508.

Richters, F. (1926): Tardigrada. In: KüKenthal, W. \& KRUMbach, T. (eds): - Handbuch der Zoologie 3: 58-61.

Sands, C. J., McInnes, S. J., Marley, N. J., Goodall-Copestake, W., Convey, P. \& Linse, K. (2008): Phylum Tardigrada: "an indiviual" approach. - Cladistics 24: 1-18. https://doi.org/10.1111/j.1096-0031.2008.00219.x

Stec, D., Gąsiorek, P., Morek, W., Kosztyea, P., Zawierucha, K., Michno, K., Kaczmarek, Ł., Рвокор, Z. M. \& Miснацсzүк, Ł. (2016): Estimating optimal sample size for tardigrade morphometry. - Zoological Journal of the Linnean Society 178(4): 776-784. https://doi.org/10.1111/zoj.12404

Stec, D., Krzywański, Ł., Arakawa, K. \& MichalczyK, Ł. (2020a): A new redescription of Richtersius coronifer, supported by transcriptome, provides resources for describing concealed species diversity within the monotypic genus Richtersius (Eutardigrada). - Zoological Letters 6: 2. https://doi.org/10.1186/s40851-020-0154-y 
Stec, D., Smolak, R., KaczmareK, Ł. \& MichalczyK, Ł. (2015): An integrative description of Macrobiotus paulinae sp. nov. (Tardigrada: Eutardigrada: Macrobiotidae: hufelandi group) from Kenya. - Zootaxa 4052(5): 501-526. https://doi.org/10.11646/zootaxa.4052.5.1

Stec, D., Vecchi, M., Maciejowski, W. \& MichalczyK, Ł. (2020b): Resolving the systematics of Richtersiidae by multilocus phylogeny and an integrative redescription of the nominal species for the genus Crenubiotus (Tardigrada). - Scientific Reports 10: 19418. https://doi.org/10.1038/s41598-020-75962-1

Thulın, G. (1928): Über die Phylogenie und das System der Tardigraden. - Hereditas Minariorum 11: 207-266. https://doi.org/10.1111/j.1601-5223.1928.tb02488.x

Received May 10, 2021, accepted September 6, 2021, published February 14, 2022

\section{Supplementary materials}

SM.01. Raw morphometric data for adults and eggs of Richtersius tertius sp. n. SM.02. Raw morphometric data for hatchlings of Richtersius tertius sp. n. SM.03. Uncorrected pairwise distances. 